\title{
The Impacts of Marketing Mix on Customer Satisfaction and Loyalty in Honey Product
}

\author{
Aldyanza Yusuf SI ${ }^{1}$, Rita Nurmalina ${ }^{2}$, M Faiz Syuaib ${ }^{3}$ \\ ${ }^{1}$ Bogor Agricultural University, School of Business, Indonesia \\ ${ }^{2}$ Bogor Agricultural University, Faculty of Economics and Management, Indonesia \\ ${ }^{3}$ Bogor Agricultural University, Faculty of Agricultural Technology, Indonesia
}

\begin{abstract}
Consumer satisfaction is one parameter to measure the success of product marketing strategy. High levels of customer satisfaction will encourage the emergence of loyalty, which can affect the sustainability of consumers purchasing history. This study aims to see the factors that influence the marketing mix (7P) to customer satisfaction and loyalty of PT. Madu Pramuka, one of honey producer company with modern beekeeping in Indonesia. Since five years ago, the sales of three superior products have not increased as well as the production volume. The study was conducted at the largest outlet of PT. Madu Pramuka whom respondents are former consumers and have made purchases at this outlet in the last three months. The data analysis using SEM gives result that physical evidence, product and location from the marketing mix influence consumer satisfaction significantly. Consumer also significantly influence the formation of consumer loyalty. Based on customer satisfaction index, honey product's consumers belong to satisfy category with value of $72.13 \%$ and fall into neutral category on customer loyalty index with value of 40.69\%.
\end{abstract}

Keywords: marketing mix, customer satisfaction, customer loyalty, honey

\section{Introduction}

Honey is a sweet liquid derived from plant nectar that is processed by bees and stored in honeycomb cells. In accordance with the character, honey is one of the food ingredients of middle and upper class consumers. Honey has benefits in various aspects, including in terms of food, health and beauty [15]. Honey contains carbohydrates, proteins, amino acids, vitamins, minerals, dextrin, plant pigments and aromatic components. In addition, honey also contains compounds that are active as antibacterial. There are three systems that act as antibacterial in honey; osmotic pressure, acidity and inhibin. All three factors, either individually or jointly, reduce the presence or growth of most contaminant microorganisms [13].

In Indonesia, one of the industries engaged in honey production and beekeeping is PT. Madu Pramuka. At the beginning, it was an idea coming from the Secretary General of the National Scout Movement who wanted to apply modern beekeeping activities in Indonesia in 1970. Business activities in the company include the sale of a variety of pure honey from tree plantations like kapok honey, rubber honey, super honey, kelengkeng honey, durian honey, mango honey, coffee honey, mahogany honey and others. In addition, PT. Madu Pramuka also provides derivative products from honey such as bee pollen, royal jelly and bee propolis. There are three superior products of PT. Madu Pramuka which are concerned in this research, including kapok honey, multiflora honey and super honey. Each type of honey has its own function and properties.

Kapok honey is produced from honey bees that are grazed in the area of a jungle forest. Physically, this honey is light brown and clear, sweet taste slightly sour. If it is harvested in the summer, the water content is less than the rainy season.
Based on Table 1, note that production and sales of kapok honey declined significantly from 2011 to 2015 . Decrease in kapok honey production was caused by unfavorable weather conditions between 2014-2015. This is the direct cause of the decline in sales. But difference between production and sales shows that people are actually looking for this kapok honey product.

In multiflora honey as delivered in Table 1, the volume of production and sales looks stagnant with a slight increase or decrease. But not all of the available products can be sold out, there is a difference of about $1.000 \mathrm{~kg}$ between the products available and the products sold. The production trend decreased by $17.81 \%$ per year, while the sales trend decreased to $32.21 \%$ per year. This shows the absorption of multiflora honey production results to the consumer has not been maximized, whereas multiflora honey is also a quality honey made from various flower nectar collected by Apis mellifera bee naturally.

Table 1: Production and sales volume (in ton)

\begin{tabular}{|c|c|c|c|c|c|c|}
\hline \multirow{2}{*}{ Year } & \multicolumn{2}{|c|}{ Kapok } & \multicolumn{2}{c|}{ Multiflora } & \multicolumn{2}{c|}{ Super } \\
\cline { 2 - 7 } & Sales & Prod. & Sales & Prod. & Sales & Prod. \\
\hline 2011 & 29.95 & 30.45 & 40.99 & 41.89 & 39.10 & 39.76 \\
\hline 2012 & 28.27 & 28.75 & 39.26 & 40.44 & 39.75 & 40.82 \\
\hline 2013 & 27.35 & 27.83 & 39.10 & 40.64 & 39.66 & 40.86 \\
\hline 2014 & 15.15 & 15.68 & 39.87 & 41.41 & 39.82 & 41.56 \\
\hline 2015 & 7.22 & 7.87 & 39.08 & 40.52 & 39.32 & 40.45 \\
\hline
\end{tabular}

Super honey is a mixture of honey bee pollen, royal jelly and pure honey, of course with more properties. Based on data obtained from PT Madu Pramuka in Table 1, super honey production increased between 2011-2014 but decreased in 2015. It is known that the production trend increased by $21.43 \%$ while honey sales trend only increased by $5.23 \%$. It shows that super honey products need more attention in terms 


\section{International Journal of Science and Research (IJSR) \\ ISSN (Online): 2319-7064}

Index Copernicus Value (2015): 78.96 Impact Factor (2015): 6.391

of marketing so that it can follow the increase in production volume.

All available data indicate that during the last five years honey production can compensate for the existing honey demand, both from kapok honey, multiflora and super honey. However, not all products produced are sold completely. According to the Ministry of Forestry in Indonesia [12], honey production of farmers in Indonesia only reached 5,000 tons per year, while the demand of honey reached 15,000 tons per year. This shows that all honey produced by PT. Madu Pramuka could be sold eventually. In addition, the selection of honey products is influenced by the origin of honey production, followed by organic attributes [4]. This makes local honey products more favorable to consumers compared to overseas products. The study also shows that consumers have a desire to pay more for local honey products. There should be an excellent opportunity to increase sales in targeting consumers who are still not fulfilled.

One way that can be used to target the consumer is to form customer satisfaction of the company's products. Consumer satisfaction is a very important driver to shape consumer loyalty and form success of a business [6], [17]. In addition, marketing efforts undertaken by the company should also be more concerned. The marketing mix falls into one of the most frequently measured parameters when researching what factors can improve a particular brand's equity. It also has seven dimensions that can affect consumer satisfaction and indirectly can generate consumer loyalty. Therefore, an analysis about the influence caused by the marketing mix of customer satisfaction and loyalty should be made so that companies can re-evaluate the company's marketing strategy.

\section{Research Objectives}

The objectives of the present study include (i) analyzing the factors of the marketing mix that affect the consumer satisfaction (ii) analyzing the influence of satisfaction on consumer loyalty (iii) providing inputs to improve customer satisfaction and loyalty to honey products based on customer satisfaction index and customer loyalty index.

\section{Methods}

This study used Structural Equation Modelling (SEM) for explanatory purposes and examined the impacts of marketing mix on customer satisfaction and loyalty. For further analysis, measurement on customer satisfaction index and customer loyalty index were also conducted. Marketing mix used in this research consists of seven dimension (7Ps), product, price, place, promotion, people, process and physical evidence. The use of 7Ps marketing mix is due to the way the company sell honey products that is not only physically tangible goods, but also put forward services. In addition, the 7Ps marketing mix is also associated with the marketing strategy applied to outlets owned by the company. The research model shown in the Figure 1 is proposed to predict the relationship of the seven marketing mix dimensions (independent variables) that are based on quality- satisfaction-loyalty model [18]. In the present work, each marketing mix dimension was measured by several indicators based on the situation on observed location of research as shown in Table 2.

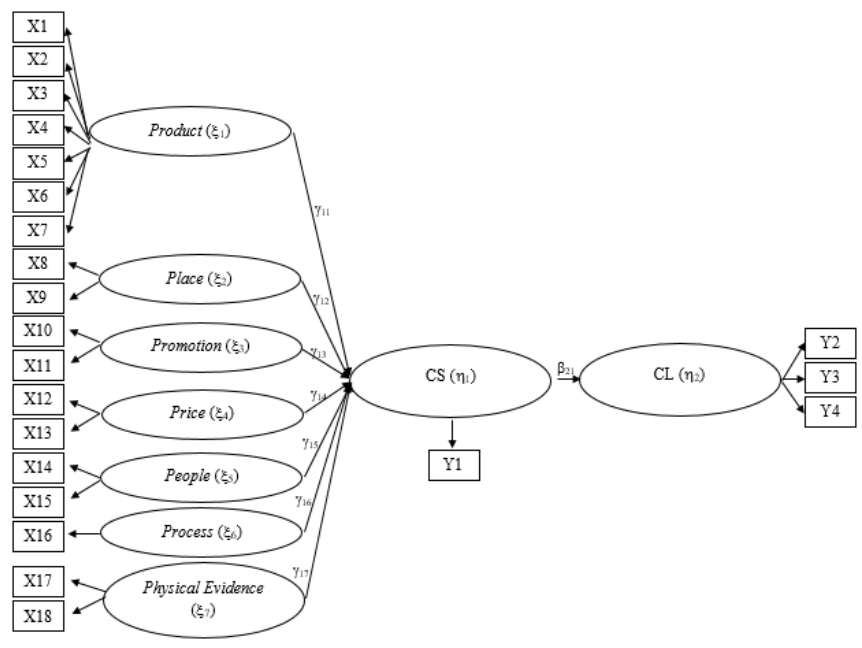

Figure 1: Research model (SEM)

Table 2: Independent and dependent variables

\begin{tabular}{|c|c|c|}
\hline Dimension & Symbol & Indicator \\
\hline \multirow{7}{*}{$\begin{array}{c}\text { Product } \\
\text { (Mowen } \\
\text { and Minor } \\
1998 \text { ) }\end{array}$} & $\mathrm{X} 1$ & Efficacy \\
\hline & $\mathrm{X} 2$ & Taste \\
\hline & $\mathrm{X} 3$ & Safety \\
\hline & $\mathrm{X} 4$ & Viscosity \\
\hline & $\mathrm{X} 5$ & Expiration time available \\
\hline & $\mathrm{X6}$ & Packaging \\
\hline & $\mathrm{X} 7$ & Brand reputation \\
\hline \multirow[t]{2}{*}{ Place } & $\mathrm{X} 8$ & Access from residence \\
\hline & $\mathrm{X} 9$ & Nearby shopping centre \\
\hline \multirow[t]{2}{*}{ Promotion } & $\mathrm{X} 10$ & Brochure and paper media \\
\hline & $\mathrm{X} 11$ & Website and online media \\
\hline \multirow[t]{2}{*}{ Price } & $\mathrm{X} 12$ & Price competition \\
\hline & $\mathrm{X} 13$ & Price compliance with quality given \\
\hline \multirow[t]{2}{*}{ People } & $\mathrm{X} 14$ & $\begin{array}{c}\text { Salesman's professionalism in handling } \\
\text { customer }\end{array}$ \\
\hline & $\mathrm{X} 15$ & $\begin{array}{l}\text { Salesman ability to understand customer's } \\
\text { needs }\end{array}$ \\
\hline \multirow[t]{2}{*}{ Process } & $\mathrm{X} 16$ & $\begin{array}{c}\text { Speed of service } \\
\end{array}$ \\
\hline & $\mathrm{X} 17$ & Clear information regarding product \\
\hline \multirow{2}{*}{$\begin{array}{l}\text { Physical } \\
\text { evidence }\end{array}$} & $\mathrm{X} 18$ & Various payment methods \\
\hline & $\mathrm{X} 19$ & Adequate parking space \\
\hline $\begin{array}{c}\text { Customer } \\
\text { satisfaction }\end{array}$ & Y1 & Overall satisfaction \\
\hline \multirow{3}{*}{$\begin{array}{c}\text { Customer } \\
\text { loyalty }\end{array}$} & Y2 & Repurchase \\
\hline & $\mathrm{Y} 3$ & $\begin{array}{l}\text { Resistance towards other similar product if } \\
\text { the price is higher }\end{array}$ \\
\hline & Y4 & Recommendation to other people \\
\hline
\end{tabular}

\subsection{Experimental design}

A face-to-face questionnaire survey, divided into three parts, was conducted in November 2016-January 2017 among consumers of PT. Madu Pramuka. Data were collected in the biggest outlet purposively so that the survey could exhibit various responds. Respondents were chosen using nonprobability sampling according to several rules. Chosen respondents should be buying honey products from PT. Madu Pramuka and at least consumed any products from the company within three months. It was completed by 126

Volume 6 Issue 7, July 2017 www.ijsr.net 


\section{International Journal of Science and Research (IJSR) \\ ISSN (Online): 2319-7064}

Index Copernicus Value (2015): 78.96 Impact Factor (2015): 6.391

people by using rule of thumb theory which counted by variable indicator used in this research.

The first part of questionnaire collected respondents' consumption behavior of honey product. It was decided to insert a number of questions about honey, asking the frequency and place for the purchase. There were also questions about several honey brands to verify their brand awareness.

The second part of questionnaire was developed, making extensive use of 5 point Likert scales to measure attitudes towards 23 different marketing tools covering all the main elements of the marketing mix and dependent variables as satisfaction and loyalty. Cronbach's alpha was used to determine the extent to which the Likert scales employed produced consistent results if measures were taken repeatedly. Coefficients over 0.6 are considered acceptable [7]. The 23 items measured in this survey had a Cronbach's alpha of 0.743 . Whilst the third part collected respondents' socio-economic information.

\section{Results}

\subsection{Respondents' Profile}

Consumers of honey are not concentrated on certain sexes. In addition, the majority of consumers are domiciled in regional honey outlets. The rest are scattered in the surrounding area. Majority occupation $(42.1 \%)$ are private employees. Average monthly income of honey consumers falls between Rp $4,000,000-\operatorname{Rp} 7,000,000$ or above that. Table 3 presents the descriptive statistics used in the estimation.

Table 3: Respondents based on demographic characteristic

\begin{tabular}{|c|c|c|}
\hline $\begin{array}{c}\text { Demographic } \\
\text { Characteristic }\end{array}$ & Category & $\begin{array}{c}\text { Percentage } \\
(\%)\end{array}$ \\
\hline \multirow{3}{*}{ Gender } & Male & 50.8 \\
\cline { 2 - 3 } & Female & 49.2 \\
\hline Residence area & Same regional as outlet & 43.6 \\
\cline { 2 - 3 } & Near outlet's regional & 28.6 \\
\cline { 2 - 3 } Occupation & Other area & 27.8 \\
\cline { 2 - 3 } & Academy & 7.1 \\
\cline { 2 - 3 } & Housewife & 15.1 \\
\cline { 2 - 3 } & Civil servant & 11.1 \\
\cline { 2 - 3 } & Private employee & 42.1 \\
\cline { 2 - 3 } & Student & 4 \\
\cline { 2 - 3 } & Professional & 1.6 \\
\cline { 2 - 3 } & Army & 0.8 \\
\hline Monthly income & Entrepreneur & 18.3 \\
\cline { 2 - 3 } & $\mathrm{Rp} 1.000 .000-\mathrm{Rp} 4.000 .000$ & 19.8 \\
\cline { 2 - 3 } & $\mathrm{Rp} \mathrm{4.000.000-Rp} \mathrm{7.000.000}$ & 43.7 \\
\cline { 2 - 3 } & $>\mathrm{Rp} 7.000 .000$ & 35.7 \\
\hline
\end{tabular}

Based on the results of the study, $57 \%$ of respondents often buy super honey at the outlet, followed by kapok honey and multiflora honey. The majority of consumers likes to buy 650 $\mathrm{ml}$ honey products. Purchasing frequency of honey consumers is every one month $(62 \%)$.

\subsection{Overall Model Fit}

In evaluating the structural equation model that has been developed, there are several steps that must be passed [8], [22]. The first stage is the overall fit of the model (overall model fit). Evaluation of the overall fit of the model is done as a basic requirement of the suitability of the model with the theory developed to analyze customer satisfaction and loyalty. However, one disadvantage of the SEM model is that the model is sensitive to the number of samples used. Large number of samples will tend to produce high chi-square values so that the model does not match. Therefore, SEM provides some alternative use of other goodness of fit indicators. Based on the evaluation that has been done, the model built in this study has met the conformity test requirements (Table 4).

Table 4: Overall model fit

\begin{tabular}{|c|c|c|}
\hline Goodness of Fit & Cut-off Value & Result \\
\hline RMR & $\leq 0,05$ atau $\leq 0,1$ & 0,016 \\
\hline RMSEA & $\leq 0,08$ & 0,073 \\
\hline GFI & $\geq 0,90$ & 0,93 \\
\hline AGFI & $\geq 0,90$ & 0,99 \\
\hline CFI & $\geq 0,90$ & 1,00 \\
\hline NFI & $\geq 0,90$ & 1,00 \\
\hline RFI & $\geq 0,90$ & 1,00 \\
\hline
\end{tabular}

\subsection{Factors which Effects Consumer Satisfaction and Loyalty}

Figure 2 shows the overall SLF value of each variable from the SEM. The SLF value is shown in each arrow that exits the indicator variable as well as the latent variable to the variable symbol and it has value more than 0.5 .

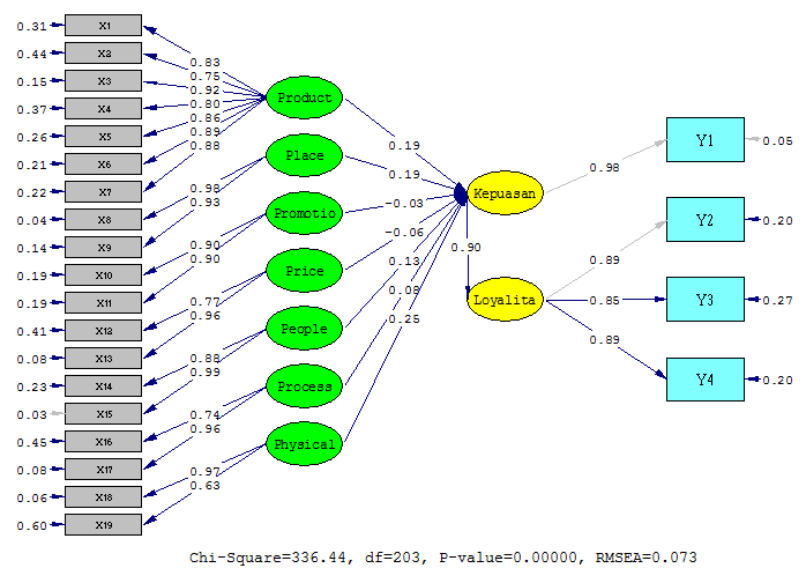

Figure 2: Standardized loading factor (SLF) value

The value of loading factor is a coefficient that can show how much relative contribution of each attribute (indicator variable) in forming exogenous latent variable [1], [9], [21]. Therefore, if each indicator variables have a SLF value greater than 0.5 then it can be said that the variable has a significant contribution to the formation of latent variables. In addition to testing the SLF values of each variable, the tvalue test is also necessary to assess its validity.

In Figure 3, the t-value of the indicator variable can be seen on the arrow leading to the variable symbol. All marketing

Volume 6 Issue 7, July 2017 www.ijsr.net 


\section{International Journal of Science and Research (IJSR) \\ ISSN (Online): 2319-7064}

Index Copernicus Value (2015): 78.96 | Impact Factor (2015): 6.391

mix indicator variables have a value of more than 1.96 . Meanwhile, the t-value cannot be seen in the satisfaction variable to the symbol $\mathrm{Y} 1$ and the loyalty variable to the symbol Y2 because the SEM model always assumes that the first indicator variable of each endogenous variable must be significant or valid. In the loyalty variable, all other indicators indicate that everything is valid.

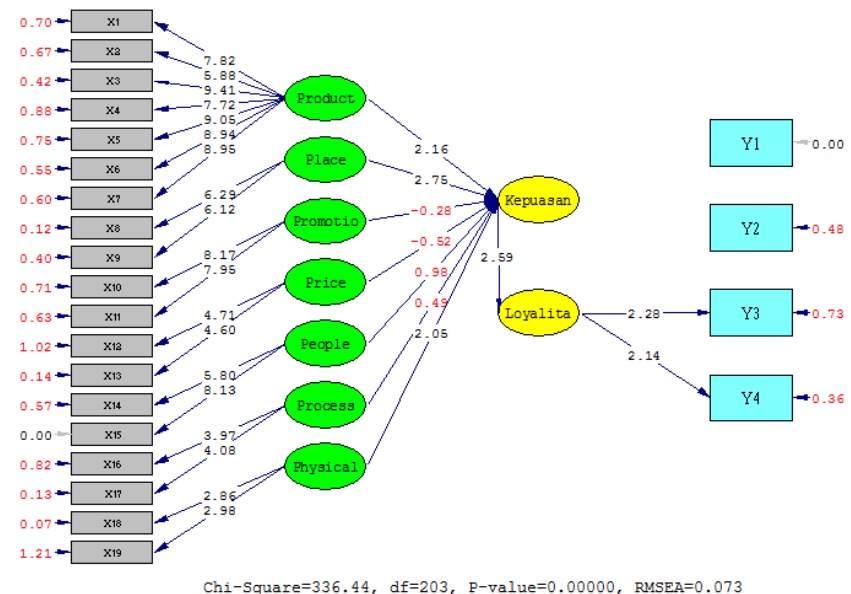

Figure 3: T-value result

More specifically, in Table 5 we can see exogenous latent variables of the marketing mix affecting customer satisfaction. The value of the construct coefficient on promotion and price has a minus sign. It signifies promotion and price precisely lead to decreased satisfaction. Although when viewed from the large coefficient value of the construct, the decrease in satisfaction is not so great. The same is also seen from the t-value of the two variables, the magnitude 0.28 and 0.58 so it is considered insignificant to the formation of consumer satisfaction PT. Madu Pramuka.

Table 5: Exogenous latent variables

\begin{tabular}{|c|c|c|c|}
\hline $\begin{array}{c}\text { Marketing Mix } \\
\text { Dimension }\end{array}$ & $\begin{array}{c}\text { Construct } \\
\text { Coefficient }\end{array}$ & t-value & Status \\
\hline Product & 0.19 & 2.16 & Significant \\
\hline Place & 0.19 & 2.75 & Significant \\
\hline Promotion & -0.03 & 0.28 & Not significant \\
\hline Price & -0.06 & 0.58 & Not significant \\
\hline People & 0.13 & 0.98 & Not significant \\
\hline Process & 0.08 & 0.49 & Not significant \\
\hline Physical evidence & 0.25 & 2.05 & Significant \\
\hline
\end{tabular}

Consumer satisfaction contributes to the formation of consumer loyalty. In this study, consumer satisfaction is based only on one indicator, that is overall satisfaction (Y1). The loading factor value of the indicator variable is 0.98 . This shows that in general the respondents conducted a careful assessment of satisfaction of the overall aspects of product sales. Furthermore, based on test results that have been done known that customer satisfaction can affect the formation of consumer loyalty. It is based on the value of endogenous latent variable loading factor of satisfaction toward endogenous latent variable of loyalty 0.90 .

The value generated by the satisfaction variable on loyalty in accordance with some previous research, where customer satisfaction has a positive and significant influence on customer loyalty [2], [3], [5], [11], [19], [20].

\subsection{Customer Satisfaction Index}

Customer Satisfaction Index (CSI) became one of the methods used to measure the level of customer satisfaction in honey products. The consumer satisfaction index is calculated on the basis of the weight of each 7P marketing mix indicator. Influence value was calculated by multiplying loading factor of each indicator with coefficient construct of each dimension. The weights are then multiplied by the percentage of satisfied answers, where the value refers to the top two boxes of agreed answers (score 4) and strongly agree (score 5) on the indicators that make up the satisfaction. The results of CSI calculations can be clearly seen in Table 6 .

Table 6: Customer Satisfaction Index

\begin{tabular}{|c|c|c|c|c|}
\hline Indicator & Influence value & Weight & CSI $(\%)$ & $\begin{array}{c}\text { Indicator CSI } \\
(\%)\end{array}$ \\
\hline $\mathrm{X} 1$ & 0.16 & 0.07 & 77.78 & 5.81 \\
\hline $\mathrm{X} 2$ & 0.14 & 0.07 & 78.57 & 5.30 \\
\hline $\mathrm{X} 3$ & 0.17 & 0.08 & 84.13 & 6.97 \\
\hline $\mathrm{X} 4$ & 0.15 & 0.07 & 53.97 & 3.89 \\
\hline $\mathrm{X} 5$ & 0.16 & 0.08 & 41.27 & 3.19 \\
\hline $\mathrm{X} 6$ & 0.17 & 0.08 & 30.95 & 2.48 \\
\hline $\mathrm{X} 7$ & 0.17 & 0.08 & 91.27 & 7.23 \\
\hline $\mathrm{X} 8$ & 0.19 & 0.09 & 54.76 & 4.83 \\
\hline $\mathrm{X} 9$ & 0.18 & 0.08 & 63.49 & 5.31 \\
\hline $\mathrm{X} 10$ & -0.03 & -0.01 & 36.51 & -0.47 \\
\hline $\mathrm{X} 11$ & -0.03 & -0.01 & 10.32 & -0.13 \\
\hline $\mathrm{X} 12$ & -0.05 & -0.02 & 53.97 & -1.18 \\
\hline $\mathrm{X} 13$ & -0.06 & -0.03 & 73.02 & -1.99 \\
\hline $\mathrm{X} 14$ & 0.11 & 0.05 & 74.60 & 4.04 \\
\hline $\mathrm{X} 15$ & 0.13 & 0.06 & 69.05 & 4.21 \\
\hline $\mathrm{X} 16$ & 0.06 & 0.03 & 92.06 & 2.58 \\
\hline $\mathrm{X} 17$ & 0.08 & 0.04 & 82.54 & 3.00 \\
\hline $\mathrm{X} 18$ & 0.24 & 0.11 & 86.51 & 9.94 \\
\hline $\mathrm{X} 19$ & 0.16 & 0.07 & 95.24 & 7.11 \\
\hline Total & $\mathbf{2 . 1 1}$ & & & \\
\hline CSI & & & & $\mathbf{7 2 . 1 3}$ \\
\hline & & & &
\end{tabular}

Based on the calculation in Table 6 , it is known that the total value of consumer satisfaction index of PT. Honey Scout is $72.13 \%$. When referring to the criteria of customer satisfaction, the value belongs to the satisfied category. Meanwhile, the value of customer satisfaction can also be seen in each indicator variable. In the product dimension, consumers feel most satisfied with brand reputation indicators (X7), followed by a sense of security in consuming products (X3). The smallest value of satisfaction is obtained from the packaging (X6), the availability of the expiration time(X5) and the viscosity of the product (X4). In place dimensions, both indicators (X8 and X9) have yielded almost the same value of satisfaction. It is also the same by both indicators of the physical evidence (X18 and X19).

\subsection{Customer Loyalty Index}

The generation of consumer loyalty index uses a method similar to customer satisfaction index. The difference in this calculation of loyalty index is the use of one endogenous latent variable, loyalty. In addition, the calculation of the CSI value is also added to the total calculation, then divided into 


\section{International Journal of Science and Research (IJSR) \\ ISSN (Online): 2319-7064}

Index Copernicus Value (2015): 78.96 | Impact Factor (2015): 6.391

two. The results of calculations from the Customer Loyalty Index can be seen in Table 7 .

\begin{tabular}{|c|c|c|c|c|}
\hline Indicator & $\begin{array}{c}\text { Influence } \\
\text { value }\end{array}$ & Weight & CSI (\%) & $\begin{array}{c}\text { Indicator } \\
\text { CSI (\%) }\end{array}$ \\
\hline Y2 & 0.89 & 0.89 & 0.34 & 87.30 \\
\hline Y3 & 0.85 & 0.85 & 0.32 & 70.63 \\
\hline Y4 & 0.89 & 0.89 & 0.34 & 85.71 \\
\hline Total & & 2.63 & & 81.38 \\
\hline CLI & & & & 40.69 \\
\hline
\end{tabular}

Based on Table 7, it is known that the consumer loyalty index of PT. Madu Pramuka has the value of $40.69 \%$. This value falls into the neutral category, where the consumer cannot be considered loyal but also cannot be considered disloyal. This shows that it is necessary to increase the effort to improve customer satisfaction in order to increase consumer loyalty.

\subsection{Managerial Implications}

The main priority in the analysis of managerial implications is the physical evidence. This is because this factor has the highest influence among other factors in the marketing mix. The indicators used are the availability of various payment facilities and adequate parking space. Indonesian's cash holdings decreased as non-cash payments increased significantly [16]. However, the use of ATMs and debit cards in Indonesia is still limited [10]. Therefore, the availability of complete payment facilities at outlets provide a significant influence on customer satisfaction. In addition, because consumers already know that the price of honey products are high enough, there is a tendency that they are reluctant to carry large amounts of cash. All non-cash payment instruments must be checked periodically to ensure the smoothness of sales transactions and increase customer satisfaction.

Product factors also significantly influence in forming customer satisfaction. The product dimension consisting of seven indicators [14] shows a large loading factor value. Based on the calculation of consumer satisfaction index, the dimension of the product that has the lowest value is the packaging and the availability of expiration time. Selection of packaging with glass material is carried out to withstand the gas that can arise from honey products. However, this turned out to be the concern of some respondents during the interview. Packaging with glass material is considered less comfortable to be brought because it could break easily. Therefore, the company can test the use of other packaging materials that can withstand the gas produced by the product but could give ease and convenience when carried. In addition, consumers are also aware that no expiration date is available on all honey products. Actually this is not necessary, given the natural honey does not have a certain expiration time as well as other food products. However, consumers will feel more secure if the packaging contained the date of production, so they are more convinced that the honey consumed even though it produces gas is a newly produced honey.
Another variable that needs attention in increasing consumer satisfaction is the location of the sale. This factor significantly affects customer satisfaction and loyalty. The outlet in Cibubur, East Jakarta has a strategic location as it is close to the residential area. Based on the distribution of respondents' residence, $43.6 \%$ live in the same region as the outlet. Access to the outlet is also easy because it is located on the left exit of Cibubur highway exit which many passed when returning home from work. Things that can be improved in the location factor is the availability of delivery systems on the purchase of a certain amount or subscription system. Implementation of the delivery system can narrow the distance that must be taken by consumers in reaching outlets. This can increase consumer satisfaction because the product more easily obtained. Subscription system can also be done because based on the purchasing frequency, as much as $62 \%$ of respondents have a frequency of purchases once a month. Delivery done every month makes it easier for consumers to get honey and also maintain the relationship of purchase with consumers.

People is a variable that has no significant effect on customer satisfaction and loyalty. Employee professionalism as well as the ability of employees to understand the needs of consumers are two indicators in the variable of human resources. But the variable is not significant in increasing consumer satisfaction because consumers buy honey products based on the fulfillment of body health. This shows the quality of employees as salespeople is not a constraint in the activity of buying and selling products of honey at outlets.

Process variables also have no significant effect on customer satisfaction and loyalty. Consumers do not really consider the speed of service as an important thing. Provision of oral product information is also not a major factor in the purchase because generally consumers can read product information on leaflets or brochures provided at the outlet. In addition, the purchase of honey products is generally based on the recommendation of others so that they already have a choice from the beginning.

Overall, customer satisfaction and loyalty of PT. Madu Pramuka is more affected by the condition and location of outlets and the quality of the products sold. Indicators in the physical infrastructure variables need to be maintained because they have been perceived quite well by consumers. While location and product variables can still be developed applying in the marketing mix in order to increase consumer satisfaction and loyalty.

\section{Conclusions}

Based on the results of the research, it can be concluded that factors of the marketing mix which significantly influence consumer satisfaction is physical evidence, place and product. People and process do not have a significant effect on customer satisfaction, even price and promotion have negative effect on customer satisfaction. Meanwhile, consumer satisfaction has a significant influence in the formation of loyalty. Honey customers are considered satisfy with the marketing mix strategy applied by the company, but

Volume 6 Issue 7, July 2017 www.ijsr.net 


\section{International Journal of Science and Research (IJSR) \\ ISSN (Online): 2319-7064}

Index Copernicus Value (2015): 78.96 | Impact Factor (2015): 6.391

cannot be considered loyal or disloyal as the customer loyalty index is only $40.69 \%$. Strategies that can be applied to improve customer satisfaction and loyalty can be started by always keeping non-cash payment facilities in order to work optimally throughout the day. Implementation of delivery system to minimize the distance between consumer and outlet can also be done to improve consumer satisfaction. The managerial implications that can be recommended is also through trials of the use of other packaging materials to replace glass and add the date of production on the packaging. Both of these things can increase consumer awareness of the quality of products so as to increase customer satisfaction and loyalty.

\section{References}

[1] Bollen KA, Structural Equation Models with Observed Variables, in Structural Equations with Latent Variables, John Wiley \& Sons, Inc, New Jersey, 1989.

[2] Budiarti A, Surachman, Hawidjojo D, Djumahir. "Brand equity and customer satisfaction as the mediation of advertisement influence and the service quality to loyalty the passenger of international flight at garuda indonesia airlines," IOSR Journal of Business and Management, 9 (2), pp. 1-15, 2013.

[3] Caruana A, "Service loyalty the effect of service quality as the mediating role of customer satisfaction," European Journal of Marketing, 36 (7), pp. 811-829, 2002.

[4] Cosmina M, Gallenti G, Marangon F, Troiano S, "Reprint of "Attitudes towards honey among Italian consumers choice experiment approach," Appetite 106, (2016), pp. 110-116, 2016.

[5] Djati SP, Darmawan D, "Pengaruh kinerja karyawan terhadap kepuasan, kepercayaan, dan kesetiaan pelanggan,” Jurnal Manajemen \& Kewirausahaan, 7 (1), pp. 48-59, 2005.

[6] Eakuru N, Mat NKN, "The application of structural equation modelling (SEM) in determing the antecedents of customer loyalty in banks in south Thailand," The bussines Review, Cambridge, 10 (2), pp. 129-139, 2008.

[7] Ghozali I, Aplikasi Analisis Multivarite dengan SPSS, Cetakan Keempat, Badan Penerbit Universitas Diponegoro, Semarang, 2006.

[8] Hair JP. Anderson RE, Tatham RI, Black WC, Multivariate Data Analysis, Prentice-Hall, New Jersey, 1998.

[9] Joreskog KG. "Latent variable scores and their uses," in LISREL 8: User's Reference Guide, 2000.

[10] Kathleen A, "Cashless in Indonesia," Journal of Southeast Asian Economies, 33 (3), pp. 364-386, 2016.

[11] Li ML, Green RD, “A mediating influences on customer loyalty: the role of perceived value," Journal of Management and Marketing Research, 2, pp. 1-12, 2011.

[12] Ministry of Forestry, "Produksi madu Indonesia" [Online]. Available at: http://www.antaranews.com/ berita/458883/produksi-madu-indonesia-5000-tonsetahun. [Accessed on July 10, 2016].
[13] Molan PC, "The bacterial activity of honey: the nature of the antibacterial activity," Bee World, 73 (1), pp. 5-28. 1992.

[14] Mowen JC, Minor M, Consumer Behaviour, Fifth Edition, Prentice-Hall, New Jersey, 1998.

[15] Mulu A, Tessema B, Derbie F, "In vitro asessment of the antimicrobial potential of honey on common human pathogens," Ethiop J. Health Dev, 18 (2), 2004.

[16] Nirmala T, Widodo T, "Effect of increasing use the card payment equipment on the Indonesian economy," Jurnal Bisnis dan Ekonomi, 18 (1), pp. 36-45, 2011.

[17] Oliver RL, Satisfaction: A behavioral perspective on the consumer, McGraw Hill, New York, 1997.

[18] Olsen SO, "Comparative evaluation and the relationship between quality, satisfaction and repurchase loyalty," Journal of the Academy of Marketing Science, 30 (3), pp. 240-249, 2002.

[19] Parasuraman A, Zeithaml VA, Berry LL, "A Conceptual Model of Service Quality and Its Implication for Future Research,” The Journal of Marketing, 49 (4), pp. 41-50, 1985.

[20] Rahmati F, Falahati A, Jamshedynavid B, "The study impact of internal marketing on customer loyalty (case study: Iran insurance company - Kermanshah province)," International Research Journal of Applied and Basic Sciences, 4 (8), pp. 218-225, 2013.

[21] Sitinjak JRT, Sugiarto, LISREL, Graha Ilmu, Yogyakarta, 2013.

[22] Wijanto SH, Structural Equation Modeling dengan Lisrel 8.8 Konsep dan Tutorial, Graha Ilmu, Jakarta, 2008 .

\section{Author Profile}

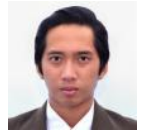

Aldyanza Yusuf received the Bachelor degree in Agroindustry Technology and Magister of Management in School of Business from Bogor Agricultural University 2014 and 2017, respectively. During 2015-2017, he involved in palm sugar production management and focus on the commercialization of the product. Then he also managed to lead a team in an organization providing services to the community. 